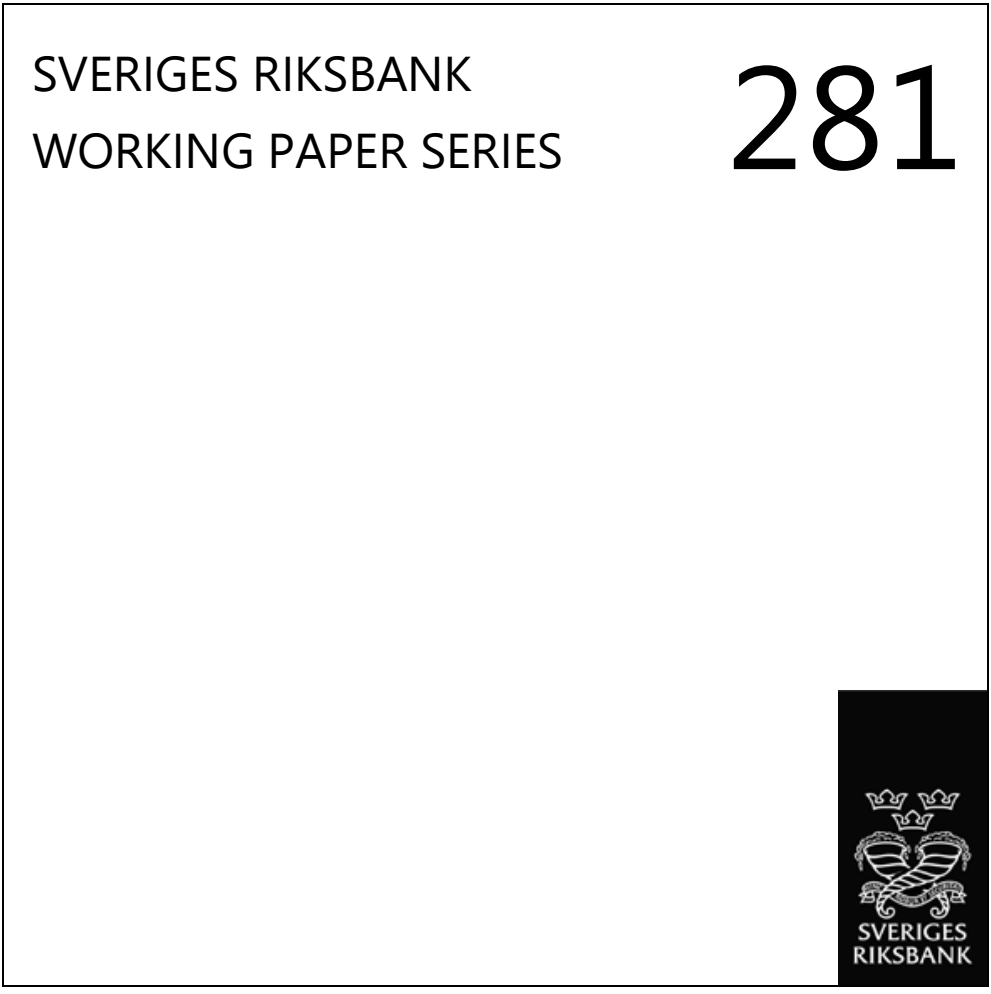

Lines of Credit and Investment: Firm-Level Evidence of Real Effects of the Financial Crisis

Karolina Holmberg

November 2013 


\section{WORKING PAPERS ARE OBTAINABLE FROM}

This paper can be downloaded without charge at: www.riksbank.se/en/Research/

Sveriges Riksbank • SE-103 37 Stockholm

Telefax : +468210531

Telephone: +4687870000

The Working Paper series presents reports on matters in the sphere of activities of the Riksbank that are considered to be of interest to a wider public.

The papers are to be regarded as reports on ongoing studies and the authors will be pleased to receive comments.

The views expressed in Working Papers are solely the responsibility of the authors and should not to be interpreted as reflecting the views of the Executive Board of Sveriges Riksbank. 


\title{
Lines of Credit and Investment: Firm-Level Evidence of Real Effects of the Financial Crisis*
}

\author{
Karolina Holmberg ${ }^{\dagger}$ \\ Sveriges Riksbank Working Paper Series
}

No. 281

November 2013

\begin{abstract}
Using Swedish bank lending data, investment data and accounting data, I examine how the financial crisis affected corporate investment through its effect on credit availability. Sensitivity to a credit supply shock is measured as credit reserves, defined as unused credit on lines of credit. I find that firms with low credit reserves reduced investment significantly more than other firms. However, it is not possible to determine that this relationship was caused by a shift in the supply of credit. Overall, I find no statistically strong evidence that the decline in investment was exacerbated by a contraction in credit supply.
\end{abstract}

Keywords: Corporate investment, Crisis, Financial Markets and the Macroeconomy, Lines of Credit

JEL classifications: E22, E44, G01, G31, G32

\footnotetext{
${ }^{*}$ I gratefully acknowledge advice from Martin Flodén. I also thank Bo Becker, Tor Jacobson, Kasper Roszbach as well as seminar participants at the Stockholm University and the Riksbank for helpful comments and discussions. I am indebted to Karl Hammenberg and Tommy von Brömsen for research assistance. The views expressed in this paper are solely the responsibility of the author and should not be interpreted as reflecting the views of the Executive Board of Sveriges Riksbank.

†Monetary Policy Department, Sveriges Riksbank, Sweden. karolina.holmberg@gmail.com
} 


\section{Introduction}

Following the financial crisis in 2008, business investment fell in many industrial countries. Obviously, this is not in itself evidence that the financial crisis caused a contraction in investments. The same adverse shock that triggered the financial crisis may also have caused a decline in aggregate demand, leading firms to cut investment. It may also have entailed an increase in uncertainty, leading firms to postpone investments. However, the financial crisis may also have led to a contraction in credit supply, and through this channel, to a decline in business investments. The purpose of this paper is to study this third channel, that is whether an adverse shift in the supply of credit caused a decline in investments.

To be able do this, it is necessary to disentangle this channel from the various demand side effects. The approach in this paper is to use a differences-in-differences method and compare investment of firms before and after the onset of the crisis as a function of their ex ante sensitivity to shocks in credit supply. The classification of firms on the basis of sensitivity to financial shocks is a common method in studies of real effects from financial frictions. However, the way in which this classification is done differs across studies.

In a recent study, Duchin, Ozbas and Sensoy (2010) (henceforth "DOS") focus on a firm's reserves of cash and assume that a credit supply shock has a greater impact on firms with low cash reserves at the onset of the crisis relative to firms with high cash reserves. DOS compare the investment of publicly traded US firms before and after the onset of the crisis and find that, consistent with the causal effect of a supply shock, the decline in investment was greatest for firms which had low cash reserves. They obtain similar results when they use other measures of exposure to a credit supply shock, such as short term debt to assets, whether the firm is ex ante financially constrained and whether the firm operates in an industry dependent on external finance.

In this study, I employ another concept of liquidity reserves. Instead of reserves in the form of cash holdings as an indicator of firms exposure to a credit supply shock, I use a measure of a firm's reserves in terms of credit. I define credit reserves as unused credit on lines of credit, i.e. funds which the firm can access as it wishes up to a pre-set limit and at conditions set in advance.

In using this measure of credit reserves, I rely on research by Sufi (2009) and Yun (2009) who find that lines of credit are important sources of liquidity for firms. I also build on a survey study by Lins, Servaes and Tufano (2010) on how and why firms use excess cash and lines of credit. They conclude that while excess cash is held to guard against future cash flow shocks, lines of credit are held to fund future growth options. Consequently, it seems well justified to include funds available on lines of credit when studying the impact of a credit supply shock on firms' real activity.

A common difficulty in empirical studies of investment is possible endogeneity of a firm's financial position. In my case, inferences will be confounded if variation in credit reserves is endogenous to unobserved variation in investment opportunities. I address this concern in a similar way as 
DOS, that is by measuring the level of credit reserves a year prior to the onset of the crisis. However, contrary to DOS, I also allow lagged credit reserves to enter as an independent variable in the regressions to control for a relationship between credit reserves and investment even in normal times. DOS use another strategy and replicate the regressions for placebo (i.e. non-existent) crisis in other time periods.

The data is a sample of 5,089 Swedish non-financial firms. The data is created by merging investment data and balance sheet and income statement data of firms with firm-level lending data from a major Swedish commercial bank. I date the onset of the financial crisis in Sweden to the beginning of the third quarter of 2008 and compare investment for the third and fourth quarter of 2008 and the first quarter of 2009 to the same quarters of 2007 and beginning of 2008 .

Overall I find no statistically strong evidence that the decline in corporate investment after the beginning of the crisis was enhanced by a negative shift in credit supply. Controlling for fundamental determinants of investment and firm fixed effects, I find a positive relationship between a firm's credit reserves and investment activities during the crisis. However, it is not possible to determine that this relationship was caused by an exogenous contraction in the credit supply during the financial crisis which caused firms with low reserves of credit to postpone or cancel investments. When I control for the impact of credit reserves in normal times, the significant impact of credit reserves during the crisis disappears.

It may be noted that my data set suggests that the same holds when sensitivity to a credit supply shock is defined in the same way as used by DOS, i.e. with reserves measured in terms of liquidity (cash reserves) instead of unused credit on credit lines. In line with DOS, I find a statistically significant relationship between cash reserves and investment activity during the crisis. But I also find that this relationship holds also in the pre-crisis period, suggesting a relationship between lagged cash and investment for other reasons than more restrictive credit conditions on behalf of banks.

As a robustness test of the results, I single out firms with the lowest levels of credit reserves and define those as "credit-constrained". I subsequently test whether those firms where particularly subject to a credit contraction during the crisis. I find that credit-constrained firms reduced investment substantially more than non-constrained firms during the financial crisis. However, the effect is not statistically significant in this case either when I control for the impact of firm-specific variables and of credit reserves in general.

In addition, I examine variation in the extensive margin of lines of credit and its effect on investment. I find that the probability of having a line of credit was reduced after the beginning of the crisis. Firms, which given their financial situation and investment opportunities, had a high probability of having a line of credit prior to the crisis, had less probability of having access to a line after the onset of the crisis. However, the empirical results do not confirm that this tigthening 
of credit standards added to the decline in investment

The outline of the paper is the following. Section 2 discusses related literature. Section 3 describes the data set. Section 4 explains the empirical method. In section 5, I present my results. Section 6 concludes.

\section{Related literature}

My work relates to the extensive empirical literature on the bank lending channel, which tests the link between shocks to banks' financial positions and the decline in credit provision to firms. Most of this literature has not focused on the impact on real activity. An early exception is Peek and Rosengren (2000), who investigated, using state level data from the US, changes in real estate activity in states with large presence of Japanese banks after the Japanese banking crisis. They found that the retrenchment of Japanese lending had a substantial impact on US real estate activity. Following the recent financial crisis, a growing number of papers study the link between credit supply shocks and real activity such as corporate investment. Several papers find supportive evidence of real effects from the recent financial crisis on investment activity. However, the evidence is mixed. There are also papers in which the evidence of real effects of the financial crisis on firm behavior are less conclusive.

In line with DOS, Almeida, Campello and Larenjeira (2011) provide evidence of a causal effect from the financial crisis to firm investment. They identify exogenous heterogeneity among firms by classifying firms according to the variation in long-term debt maturity. In particular, they compare capital expenditure of firms with more than 20 percent of their long-term debt maturing during 2008 to other firms. They find that firms with a large fractions of their long-term debt maturing at the time of the crisis cut capital expenditures more than otherwise similar firms that had less need for refinancing long-term debt during the crisis.

Campello, Graham and Harvey (2010) use survey evidence to study how financial constraints affected corporate behavior during the financial crisis. They ask managers directly whether their firms were financially constrained in the sense that companies' operations were affected by the cost or availability of credit. They find that constrained firms planned to cut employment and capital investment significantly more than unconstrained firms. Differences between constrained and unconstrained firms became more significant as the crisis unfolded. They also note that around half of the firms categorized as constrained cited difficulties in initiating or renewing a credit line. Ivashina and Sharfstein (2010) show that banks cut lending sharply to the corporate sector and that part of the retrenchment was likely to be due to a shift in credit supply. Campello, Giambona, Graham and Harvey (2011) also find survey evidence of real effects on investment of the financial crisis. In particular, they study how cash holding and credit lines affected firms' investment plans. 
Their results indicate that access to credit was scarce during the crisis and that lines of credit had a significant positive impact on corporate investments, in particular for firms with large cash holdings.

Claessens, Tong and Wei (2011) draw different conclusions. They identify different transmission channels of the financial crisis, a trade channel, a domestic demand channel and a financial channel. They study accounting data of manufacturing firms from 42 countries. To isolate the financial channel, they assume that if an adverse credit supply shock would play an important role for firms, it should be reflected in the performance of those firms that rely more on external finance for investment and working capital relative to firms that rely less on external financing. They find that while the trade and demand channels appear to have played significant roles for firms real performance, the evidence of a financial channel is considerably weaker.

In a similar vein, Kahle and Stulz (2011) argue that important features of the financial and investment policies of firms are inconsistent with a strong impact of a bank credit supply shock. Among other things, they find that firms which were more bank-dependent before the crisis (small firms, unrated firms and highly financially constrained firms) did not reduce their capital expenditure more than other firms. Furthermore, these firms decreased their net equity issuance during the first year of the crisis rather than increase it. Instead, Kahle and Stulz find evidence that an adverse demand shock and a general increase in risk during the crisis played a dominant role in explaining firms' investment policies.

My study also relates to empirical work on the use of bank lines of credit by firms both in general and during the financial crisis. Sufi (2009) and Yun (2009) show that lines of credit are important sources of liquidity for firms. Yun studies how corporate governance influences firms' choices between cash and lines of credit. Sufi examines which types of firm that tend to use lines of credit. He finds that the use of cash-flow based financial covenants by banks in the U.S. imply that lines of credit are a viable liquidity substitute only for firms that maintain high cash flow. In contrast, firms with low cash flow are less likely to obtain a line of credit, and they rely more on cash in their liquidity management. Lins, Servaes and Tufano (2010) examine whether firms use credit lines and cash holdings to hedge different risks. Their results indicate that cash is employed as a general insurance policy against poor cash-flow realizations. Lines of credit, on the other hand, are employed when future financing needs are high. Focusing on the financial crisis, Ivashina and Scharfstein (2010) document that firms drew increasingly on their lines of credit during the crisis to ensure that they had access to funds. Campello, Giambona, Graham and Harvey (2011) show that credit-constrained firms drew down their lines of credit during the crisis but also faced difficulties in renewing new credit lines. 


\section{Data}

The sample consists of quarterly data on Swedish firms, aktiebolag (by approximation the equivalence of US corporations). It includes both large, listed firms and smaller firms. The data exist over the period 2002 - 2008 and have been created by merging firm-level data from three sources: balance sheet and income statement data from the Swedish credit bureau, Upplysningscentralen, bank-lending data from a major Swedish commercial bank and investment data from Statistics Sweden.

The bank lending data have a monthly frequency and have been converted to quarterly data by using observations from the last month in each quarter. Indicator variables in this data set, for instance whether the firm has a line of credit or not, have been transformed to quarterly data by assigning a positive value for the quarter if the firm has a line of credit for at least two months of the quarter.

The accounting data and investment data sets are based on financial statements of firms. A problematic aspect is that in Sweden, as in many other countries, many firms have considerable discretion in choosing fiscal year period for their financial statements. In particular, only about half of the Swedish firms have a fiscal year that coincides with a calender year. Therefore, regardless of whether the aim is to transform the data to yearly data or to quarterly data, how to periodize the data is an issue. In many empirical studies of firm investment in the literature, this problem does not appear as they are based on only listed firms for which the fiscal year tend to correspond to a calender year.

In the accounting data set from the Swedish credit bureau, I have periodized to quarters by assigning the data to the quarters over which the fiscal year of the firm spans. For example, the data of a firm with a fiscal statement covering the period from July 1, 2007 to June 30, 3008 will be assigned to the last two quarters of 2007 and the first two quarters of 2008 . In the investment data set compiled by Statistics Sweden, the data have been assigned to the calender year to which the main part of the fiscal year refers or, in the case the fiscal year covers the last six month of one year and the first six month of next year, to the second year. In the above example, the method of Statistics Sweden implies that the investment data of the firm are assigned to 2008.

Admittedly, the fact that the accounting data and the investment data are transformed to quarterly data by means of different methods, creates some inconsistency. However, in half of the observations, in which calender year and fiscal year coincide, this is not an issue. And in a bit more than another third of the observations, the result is that accounting data lag the investment data by one or two quarters, which is not an uncommon assumption in empirical models of investment. In approximately 15 percent of the observations, the investment data lag the accounting data by one quarter, which is more unfortunate. However, in the appendix, table A2, I display the results of regressions over different subsamples of firms according to their closing 
dates of financial statements. These results show that the mismatches between the accounting data and the investment data do not bias the results in any noticeable way. It may also be noted that it is only for flow variables such as investment and cash flow that the two methods yield different dating. Stock variables in the accounting data set and used in the analysis, such as the capital stock, are assumed to remain constant over the quarters of the fiscal year. That is, the value of the variable at the end of the fiscal year is assigned to the last quarter.

I make the following adjustments of the sample. I confine the sample to non-financial firms. I remove observations which have unrealistic values for some variables, for instance negative debt. Following DOS, I also remove the smallest firms in the sample, in my case firms with less than three employees or with less than one million SEK in total assets. With the aim of excluding inactive corporations, I require that the annual reporting of the firm is consecutive and that the firm has reported an operating income each year. Furthermore, I remove firms whose bank-specific debt, according to the bank lending data, amounts to less than 80 percent of its total bank debt, according to the accounting data. The aim is to confine the sample to firms which have the commercial bank in question as its main bank. This will be important for instance when I group firms after access to a line of credit. I then want to minimize the likelihood that a firm is a customer of the bank from which I have data, has no line of credit with the bank, but has a line of credit with another bank.

Finally, I winsorize firm-specific variables expressed in ratios at the $1^{\text {st }}$ and $99^{\text {th }}$ percentiles to lessen the influence of outliers. After these removals, the sample over the full time period consists of 7,089 firms and over the pre-crisis and crisis period of 5,089 firms. Table 1 displays some summary statistics for the sample of firm.

\section{Empirical method}

To analyze the direct effect of the financial crisis on investment, I employ a standard model of corporate investment with financing frictions. ${ }^{1}$ I estimate the model with a differences-indifferences approach. That is, I examine firms' investment before and after the outbreak of the crisis as a function of their ex ante sensitivity to a credit supply shock and of proxies for investment opportunities. Hence, the outbreak of the crisis is "the treatment".

I define a firm's sensitivity to an adverse credit supply shock as a function of its credit reserves, where credit reserves are unused credit on lines of credit. Lines of credit are precommitted credit which allow firms to borrow up to a certain amount at a pre-set interest rate. When banks aim to tighten credit conditions, they are free to reduce the supply of term loans, i.e. loans not under commitment. But their possibilities to reduce the supply of loans under commitment are more

\footnotetext{
${ }^{1}$ See for instance Fazzari, Hubbard and Petersen (1987).
} 
limited. In this way, loan commitments may protect firms from a credit contraction, as argued by James (2009).

The estimated equation is of the following form in the benchmark regressions:

$$
\text { Inv }_{i t}=\alpha_{i}+\beta_{1} \text { Post }+\beta_{2}\left(\text { Post } * \text { Credit reserves }_{i t-4}\right)+\beta_{3} \text { Credit reserves }_{i t-4}+\beta_{4} X_{i t}+\varepsilon_{i t}
$$

where

$I_{n v}=\left(\frac{I}{K}\right)_{i t}$ and $I$ are investment and $K$ is capital stock. Calculations of the replacement cost of capital are shown in the appendix.

Post is an indicator variable equal to one for periods after the outburst of the crisis.

The variable Credit reserves is (total line of credit-used credit)/total assets.

$X$ is a vector of variables to measure investment opportunities. The control variables I use are cash flow and growth in sales. The exact definitions of these variables are provided in the appendix.

The model is similar to the one used by DOS. However, as explained in the introduction, they use cash reserves (cash and short-term investments over total assets) to measure a firm's sensitivity to a credit contraction. In addition, studying US data, DOS define the beginning of the financial crisis to the third quarter of 2007. I adjust the dating to Swedish conditions and date the beginning of the crisis to the beginning of the third quarter of 2008. It can be argued that the financial crisis had its major repercussions in Swedish financial markets after that Lehman Brothers filed for bankruptcy in September 2008. ${ }^{2}$ The differences-in-differences analysis will be conducted by comparing the crisis period - the third and fourth quarters of 2008 and the first quarter of 2009 - to a pre-crisis period - the third and fourth quarters of 2007 and the first quarter of 2008 .

The model is estimated with fixed effects to control for time-invariant variables such as timeinvariant variation in investment opportunities. Standard errors are heteroskedasticity-consistent and clustered at the firm level.

A difficulty when estimating investment equations with financial variables is that those variables may be endogenous to unobserved changes in investment opportunities, in which case the estimates will be biased. To handle this problem, I use firms' credit reserves lagged four quarters in equation (1). That is, I use credit reserves measured one year prior to the financial crisis as instruments for credit reserves during the financial crisis. The assumption is accordingly that credit reserves $_{t-4}$ are correlated with credit reserves $t_{t}$ but unrelated to unobserved changes in investment opportunities (i.e. unobserved firm-specific demand shocks) between the pre-crisis period and the crisis period.

As an additional check that inference is not confounded by biased estimates, I also allow lagged credit reserves to enter as an variable on its own in the regressions. The purpose is to verify that credit reserves had an independent importance for investments during the financial crisis, i.e. that

\footnotetext{
${ }^{2}$ See for instance the assessment of the Riksbank in the Monetary Policy Report 2008:3.
} 
any relationship I may find is not due to a general relationship between lagged credit reserves and investment.

Another issue when interpreting my results concerns sample selection. The approach I use is naturally limited to studying the intensive margin (firms with a credit line). However, it is conceivable that the likelihood of having a line of credit declined after the outbreak of the crisis. This could have occurred either because banks did not renew existing lines at maturity or because they were more reluctant to extend new lines. In either case, the effect of the credit contraction may be larger when taking the extensive margin into account. To assess whether this effect is present, I estimate the following model:

$$
\operatorname{Pr}[L=1]_{i t}=\alpha+\beta_{1} \text { Post }+\beta_{2} X_{i t}+\varepsilon_{i t}
$$

where $L$ is equal to 1 if a firm has a line of credit and 0 otherwise and $X_{i t}$ is a vector of firm-specific variables determining the probability of having a line of credit.

It turns out that the estimate of $\beta_{1}$ is strongly significant and with the expected negative sign. Therefore, I will modify and re-estimate (1) to examine the impact on investment of more limited access to lines of credit. A possible way to do this and the estimation results are presented in section 5.5.

\section{Results}

\subsection{Firms' investment before and after the financial crisis - differences in means}

Before turning to the statistical analysis, table 2 presents comparisons of average investment before and after the onset of the crisis for different groups of firms. The comparisons are based on crosssectional averages of firm-level time-series averages over the three quarters before and after the crisis.

Panel 1 of table 2 shows that for the whole sample of firms, investment was 10.3 percent lower in the crisis period compared to the pre-crisis period. The magnitude of the decline is within the same magnitude as in the aggregate statistics. According to the Swedish national accounts, as reported by Statistics Sweden, business investment was 8.6 percent lower on average during the last two quarters of 2008 and the first quarter of 2009 compared to the same period one year earlier.

Panel 2 of table 2 compares the change in investment for firms with and without a line of credit. On average, firms with a line of credit reduced investment more during the crisis than firms without a line of credit. 
In Panel 3 of table 2, I group firms based on their level of credit reserves during the sample period. The group of firms labeled low credit reserves is firms in the lowest 25 percentiles of credit reserves, and the group labeled high credit reserves is the complement. Investment declined by 12.9 percent for firms with low credit reserves, compared to a decline by 5.7 percent for firms with more ample credit reserves. The results suggests that shortage of credit hurt investment in particular for firms lacking sufficient credit reserves in the form of precommitted credit.

In the bottom panel of table 2, I replicate DOS and group firms based on their level of cash reserves, with the similar percentile cuts as in panel 3. My sample supports the finding of DOS, namely that in particular firms with low cash reserves reduced investment after the onset of the crisis.

In the sections below, I will examine whether these patterns are robust to statistical analysis.

\subsection{Investment and cash reserves: replicating DOS}

I begin by examining whether the results of DOS also hold in my sample of firms. That is, I estimate (1) with cash reserves as a measure of a firm's sensitivity to a credit supply shock. Similar to DOS, I measure the level of cash several quarters prior to the outbreak of the crisis.

The following differences compared to DOS should be noted. DOS examine a sample of public traded firms for which they can calculate a proxy for Tobin's Q based on market valued assets. I use growth in sales as a proxy for investment opportunities. As noted earlier, I also adopt the definition of pre-crisis and crisis period to Swedish conditions. In addition, while DOS use a fixed date at which they measure the level of cash (the second quarter of 2007), I use a lag of four quarters. The reason is that I want to also add cash reserves as an independent variable. Without this variation in cash reserves, the variable falls out of the regression when I estimate with fixed effects.

Table 3 displays the results of these estimations. Similar to DOS, I find that firms with a high level of cash prior to the crisis reduced investment less than other firms. The first two columns show results of regressions without any firm-specific time-varying control variables but with firm fixed effects.

The estimates in the first column imply that quarterly investment declined by 0.49 percentage points for the average firm following the onset of the crisis. In relation to the unconditional mean of 2.88 percent of capital per quarter (see table 1), it implies a decline in investment of 17 percent. The magnitude of the decline is larger than what is suggested by the difference in means calculations shown in panel 1 of table 2 . However, table 2 does not take into account that the panel of firms is unbalanced. In the regressions in column 1 of table 3 this should be dealt with when I adjust for fixed effects.

The second column of table 3 shows that investment declined less for firms with a high level 
of cash one year prior to the crisis. The quantitative impact is small but significant. (While the general level effect of cash is removed with the fixed effects, the interaction with the crisis indicator still makes it possible to infer the impact from the firm's level of cash prior to the crisis.) As shown in the third column, the effect of pre-crisis cash reserves remains when I control for contemporaneous investment opportunities as measured by growth in sales and the ratio of cash flow to assets.

In the fourth column, I add lagged cash reserves as an independent variable. With this variable in the regression equation, the significant impact of pre-crisis cash on investment disappears. This suggests that cash in previous quarters is related to investment activity in general, i.e. not only during the financial crisis. And when this relationship is taken into account, there is no additional impact of cash reserves during the financial crisis. A conclusion is that, when cash is used as a measure of sensitivity to a credit supply shock, there is no evidence that firms with a higher sensitivity to a credit supply shock (firms with low cash reserves) reduced investment more than other firms. These findings contradict the findings of DOS. They find a statistical significant impact of cash reserves on investment which holds up only during the financial crisis and not during placebo crisis.

\subsection{Investment and credit reserves}

In this section, I examine the relationship between investment and a firms' exposure to a credit supply shock using the alternative measure of exposure to a credit supply shock proposed in this study, namely a firm's credit reserves. I expect that firms with little unused credit on their lines of credit when the crisis hit - low credit reserves - reduced investment more than firms with abundant credit reserves.

Table 4 shows the result of regressing equation (1) with a firm's level of credit reserves on the right hand side of the equation. As seen in the second column in table 4, this way of characterizing a firm's sensitivity to a credit supply shock also shows a significant negative relationship between sensitivity and investments. Firms with higher level of credit reserves reduced investment less than firms with lower level of reserves. The significance remains when I control for firm-specific investment opportunities. In the fourth column, I allow also lagged credit reserves to enter as an independent variable. As in table 3, this modification alters the result in the sense that the impact of credit reserves during the crisis period is no longer significant. In other words, using firms' level of credit reserves as a measure of sensitivity to a credit supply shock gives similar results as when cash reserves is used. Overall, these results do not support that the decline in investment during the financial crisis was reinforced by a negative shift in the supply of credit.

It is of course conceivable that neither of those measures is a good approach to identify firms which ought to have been the most affected by a contraction in credit on behalf of the banks. It 
is, for instance, possible that there was no general relationship between the level of credit reserves and a firm's degree of sensitivity to an exogenous credit supply shock, but that firms with the lowest levels of reserves were still hurt by a shortage of credit during the financial crisis.

With the aim of examining whether this was the case, I single out firms with the lowest levels of credit reserves and define those as "credit-constrained". As before, due to endogeneity concerns, I measure credit reserves with a lag of four quarters. I define firms with credit reserves at or below the $10^{\text {th }}$ percentile as credit-constrained. This corresponds to firms with credit reserves amounting to 3 percent of assets or less, compared to an average of 8 percent for unconstrained firms. In relation to total size of the line of credit it amounts to an average usage ratio of 55 percent compared to 26 percent for the average unconstrained firm. Table 5 presents some other summary statistics for the group of credit-constrained firms compared to the full sample of firms. The number of credit constrained firms is small, only 896 firms, but the average size is, somewhat surprisingly, substantially larger than the average firm in the full sample, both in terms of total assets and number of employees.

Table 6 shows the results of these estimations. In these regressions, I also include cash reserves with a lag of four quarters as an extra control variable as my earlier results indicated that this variable is related to investment in general. As shown in the second column, the coefficient of the interaction term of credit-constrained and after the crisis has the expected negative sign and is statistically significant. The quantitative effect is such that investment declines by 0.46 percent of capital for the average unconstrained firm and 0.77 percent of capital for the average constrained firm.

However, as before, the significance disappears when I control for the impact of lagged credit reserves in general. Hence, for this group of firms, which has particularly limited possibilites for relying on already committed credit for financing needs during the financial crisis, it also does not appear that credit reserves were more important during the crisis than normally.

Next I consider whether the results differ when the definition of the group of credit-constrained firms is altered. In table 7, I expand the definition of credit-constrained firms to include firms below the $15^{\text {th }}$ and the $20^{\text {th }}$ percentiles. It turns out that, by expanding the groud of credit-constrained firms, there is no longer any significant impact on investment after the onset of the crisis.

Taken together these results lend support to the interpretation that the supply of credit did not shift inwards during the financial crisis in a way that had a significant impact on firms' investment.

\subsection{Investment and total reserves}

So far, I have defined reserves as either reserves in the form of unused credit or in the form of cash. However, to the extent that lines of credit and cash are substitutable forms of financing for firms, it is also relevant to examine the sensitivity of credit reserves and cash to investments during the 
crisis. In the survey on the relation between firm's financing conditions and corporate behavior during the financial crisis, Campello, Graham and Harvey (2010) find that four in ten of the firms say that they use cash reserves to finance investment if they are unable to borrow. One would then expect for at least some of the firms with low credit reserves that cash reserves were used instead as an alternative means of financing investments.

Therefore, in table 8, I group firms on the basis of total reserves, defined as the sum of credit reserves and cash reserves. As before, I measure the financial positions with a lag of four quarters to minimize the risk of biased estimates. I repeat the regressions of table 6 , that is I define firms in the lowest $10^{t h}$ percentile of total reserves as constrained in terms of financing means. The general effect from total reserves has the expected positive sign and a significant impact. However, the effect of being constrained during the financial crisis in the sense of having a low level of cash and credit reserves is insignificant in all specifications. Hence, there is also no evidence with this definition of constraint of a reduction in credit supply on investment during the financial crisis.

\subsection{Investment and the probability of having a line of credit}

In this section, I extend the analysis to take into account another aspect of the credit contraction, namely that difficulties in gaining access to a line of credit appear to have increased after the crisis began. As shown in figure 1, the share of firms which had access to a line of credit decreased as from the third quarter of 2008. The reduction in the share of firms with a line of credit was not limited to small firms. Similar reductions are visible in the figure for firms in the top decile of firms in terms of asset as well as in the top percentile.

This development is confirmed in a multivariate probit regression with an indicator variable equal to one for the crisis period and with controls for changes in firm fundamentals. Table 9 shows results of estimations of equation (2), where I have used the following firm-level variables: cash flow, total assets, growth in sales, volatility in cash flow as well as an indicator variable for whether the firm is part of group or not. The results imply that a firm, which given its financial situation and investment opportunities would have had access to a line of credit prior to the crisis, had significantly less probability of having a line after the onset of the crisis.

I now proceed to examine whether this credit contraction, in the form of more restrictive access to lines of credit, had an impact on investment activity. The approach is to estimate investment after the onset of the crisis as a function of a change in access to a line of credit and a change in the likelihood of having a line of credit as well as firm-specific control variables. The equation is of the following form. 


$$
\begin{aligned}
\text { Inv }_{i t}= & \alpha+\beta_{1}\left(\text { Line }_{t-1}-\text { Line }_{t}\right)+ \\
& \beta_{2}\left(\operatorname{Pr}\left[\text { Line }=1 \mid X_{t-1}\right]-\operatorname{Pr}\left[\text { Line }=1 \mid X_{t}\right]\right)+\beta_{3} X_{i t}+\varepsilon_{i t}
\end{aligned}
$$

The term $\left(\right.$ Line $_{t-1}-$ Line $\left._{t}\right)$ singles out firms which had access to a line of credit prior to the crisis but not after the crisis (or vice versa). If access to a line of credit was a truly exogenous variable in equation (3), introducing this first term in the investment equation would in principle be sufficient to capture the impact of this kind of credit tightening on investment. Exposure to the credit supply chock would then be captured by those firms which had a line of credit in the pre-crisis period but were cut off from the line in the crisis period. However, in reality, a firm's access to a line of credit is a function of firm-specific variables which are not all exogenous in the investment equation. In other words, endogeneity problems are likely to be present.

To deal with this, I include probit estimates of changes in the probability that a firm has a line of credit, the term $\left(\operatorname{Pr}\left[\right.\right.$ Line $\left.=1 \mid X_{t-1}\right]-\operatorname{Pr}\left[\right.$ Line $\left.\left.=1 \mid X_{t}\right]\right)$. The probit model is the same model as in equation (2), but I leave out the crisis dummy and estimate the model only for the pre-crisis period (i.e. the last two quarters of 2007 and the first quarter of 2008).

I subsequently use the model to predict the probability of having a line of credit in the postcrisis period. That is, I update the model with firm-level variables of period $t$. For example, a positive difference between $\left(\operatorname{Pr}\left[\right.\right.$ Line $\left.\left.=1 \mid X_{t-1}\right]\right)$ and $\left(\operatorname{Pr}\left[\right.\right.$ Line $\left.\left.=1 \mid X_{t}\right]\right)$ reflects a change in firmlevel variables such that the likelihood of having a line of credit has decreased, given the credit conditions during the pre-crisis period. In this way, this term captures the firm-level influence on the probability of having a line of credit.

As a result, with this term in the regression equation, the influence from firm level variables on the probability of having a line, which would otherwise bias the estimate of $\beta_{1}$, is dealt with.

A negative estimate of $\beta_{1}$ will confirm the hypothesis that a tightening of the terms under which lines of credit were granted had a negative impact on investments. The expected sign of $\beta_{2}$ is positive as firms' balance sheets and investment opportunities are likely to have deteriorated between the pre-crisis and post-crisis period.

The results of these regressions are shown in table 10. In the first two columns of table 10, I employ pooled regressions as the time period over which I estimate equation (3) is limited to only three quarters, the third and fourth quarters of 2008 and the first quarter of 2009. In the third to the eighth column, the equation is estimated over a cross-section of firms for each of the quarters during the crisis.

In most of the specifications, the estimate of $\beta_{2}$ shows a significant positive effect on investments reflecting the general deterioration in firms' financial variables in the crisis period compared to the 
pre-crisis period. $\beta_{2}$ captures the impact of the control variable, the change in probability of having a line of credit. The variable of main interest is the change in actual credit line access, $\left(\right.$ Line $_{t-1}-$ Line $\left._{t}\right)$. In all specifications, the estimate of $\beta_{1}$ has the expected negative sign. It is also worth noting that the point estimates of $\beta_{1}$ are substantially more negative for the first quarter of 2009, when the largest drop in aggregate investment occurred, than for the preceding quarters. However, in none of the specifications is the impact on investments significantly different from zero. Hence, it is not possible to say with any statistical degree of certainty that the credit tightening in the form of reduced access to lines of credit contributed to the fall in firm investment.

\section{Conclusions}

During the financial crisis, there was widespread concern that severe financial stress among financial intermediaries would cause a general contraction in the supply of credit. This could in turn have negative effects on the real economy, inter alia by forcing firms to delay or postpone investment. In this study, I assess the impact of the financial crisis of 2008 on corporate investment through its effect on credit availability. The approach is to compare firms' investment before and after the onset of the crisis as a function of their ex ante sensitivity to a credit supply shock, controlling for firm fixed effects and time-varying measures of investment opportunities. Sensitivity to a credit supply shock is measured as a function of a firm's level of credit reserves, defined as unused credit on lines of credit. The hypothesis is that a negative credit supply shock causes firms with low credit reserves to reduce investment more than other firms.

The data is a sample of 5,089 Swedish firms and comprises of both large, listed firms and smaller firms. The approach is similar to Duchin, Ozbas and Sensoy (2010). However, the way I measure sensitivity to an adverse shock is different and motivated by empirical studies on firms' use of lines of credit (Sufi (2009) and Yun (2009)). I address endogeneity concerns by measuring credit reserves a year prior to the onset of the crisis and by controlling for a possible relationship between credit reserves and investment in normal times.

The results show that firms with low credit reserves reduced investment significantly more than other firms during the financial crisis. The results hold when I control for firm-specific investment opportunities and firm fixed effects. However, when I control for the impact of credit reserves in non-crisis times, there is no additional significant impact from low credit reserves during the crisis. I also verify that firms in the lowest $10^{\text {th }}$ percentile of credit reserves also did not reduce investment significantly more than other firms. It could be argued that those firms would have had particularly little possibility of handling difficulties in obtaining new credit by drawing on already committed credit. Overall, the results do not support that the decline in investment during the financial crisis was reinforced by an exogenous shift in the supply of credit. 
As a robustness test, I run regressions where I use the same measure of exposure to a credit supply credit as employed by Duchin, Ozbas and Sensoy, that is reserves in terms of cash. However, contrary to these authors, also with this measure of a firm's crisis exposure, I find no support for real effects on firms' investment behavior.

In a final step, I examine the extensive margin of lines of credit. I find that the probability that a firm had access to a line of credit was reduced after the onset of the crisis. However, this tightening of credit conditions can also not be shown with statistical certainty to have added to the decline in investment.

In sum, the empirical results in this study suggest that the contraction in credit supply during the financial crisis was not sufficiently severe or persistent to cause investment of Swedish firms to decline significantly. On an intuitive level, the results may seem puzzling given that the financial crisis is often described as a complete meltdown of certain markets for the financial intermediaries or as a full-blown financial panic. However, it should be recalled that a broad range of measures of unprecedented scale was undertaken by central banks and other authorities to secure the provision of liquidity in the economy, and Sweden was no exception. It is possible that the real effects may have been substantially larger in the absence of such action. In other words, those measures may have been successful in counterbalancing the negative effects on credit supply of the financial crisis. 


\section{References}

Almeida, Heitor, Murillo Campello and Bruno Laranjeira (2011), "Corporate Debt Maturity and the Real Effects of the 2007 Credit Crisis", forthcoming Critical Finance Review

Campello Murillo, Erasmo Giambona, John R. Graham and Campbell R. Harvey (2011), "Access to Liquidity and Corporate Investment in Europe During the Financial Crisis", unpublished working paper, Duke University, University of Illinois and University of Amsterdam.

Campello, Murillo, John R. Graham and Campbell R. Harvey (2010), "The Real Effects of Financial Constraints: Evidence from a Financial Crisis", Journal of Financial Economics 97, 470-487

Claessens, Stijn, Hui Tong and Shang-Jin Wei (2011), "From the Financial Crisis to the Real Economy: Using Firm-level Data to Identify Transmission Channels", NBER Working Papers No. 17360

Duchin, Ran, Oguzhan Ozbas and Berk A. Sensoy (2010), "Costly external finance, corporate investment and the subprime mortgage credit crisis", Journal of Financial Economics 97, 418-435.

Fazzari, Steven, R. Glenn Hubbard and Bruce Petersen (1988), "Financing Constraints and Corporate Investment", Brooking Papers on Economic Activities, 141-195.

Ivashina, Victoria and David Scharfstein (2010), "Bank Lending During the Financial Crisis of 2008", Journal of Financial Economics 97, 319-338.

James, Christopher M (2009), "Credit Market Conditions and the Use of Bank Lines of Credit", Federal Reserve Bank of San Francisco Economic Letter 2009-27.

Kahle, Kathleen M. and René M. Stulz (2011), "Financial Policies, Investment, and the Financial Crisis: Impaired Credit Channel or Diminished Demand for Capital?", Fisher College of Business Working Paper No. 2011-3.

Lins, Karl V., Servaes Henri and Tufano, Peter (2010), "What Drives Corporate Liquidity? An International Survey of Cash Holdings and Lines of Credit", Journal of Financial Economics 98, $160-176$.

Peek, Joe and Eric S. Rosengren (2000), "Collateral Damage: Effects of the Japanese Bank Crisis on Real Activity in the United States", The American Economic Review 90, 30-45.

Sufi, Amir (2009), "Bank Lines of Credit in Corporate Finance: An Empirical Analysis", The Review of Financial Studies 22, 1057-1088. 
Sveriges Riksbank Monetary Policy Report 2008:3

U.S. Bureau of Economic Analysis (2003), "Fixed Assets and Consumer Durable Goods in the United States, 1925-97", U.S. Government Printing Office, Washington, D.C.

Yun, Hayong (2009), "The Choice of Corporate Liquidity and Corporate Governance", Review of Financial Studies 22, 1447-1475. 


\section{Tables and figures}

Table 1. Summary statistics

\begin{tabular}{lll}
\hline & Mean & Standard deviation \\
\hline Investment/capital (\%) & 2.881 & 4.857 \\
Total assets (\$ millions) & 31.857 & 677.143 \\
Growth in sales (annual rate) & 6.281 & 13.207 \\
Cash flow/assets (\%) & 11.851 & 11.204 \\
Cash reserves/assets & 0.120 & 0.142 \\
Credit reserves/assets & 0.083 & 0.083 \\
Used amount/credit line (\%) & 26.462 & 35.324 \\
\hline
\end{tabular}

Table Notes: This table reports summary statistics for the main sample of firms, that is the sample used in the estimations in tables $3-9$. It covers firms with access to a line of credit. The time period includes a pre-crisis period corresponding to the third and fourth quarters of 2007 and the first quarter of 2008 and a crisis period corresponding to the third and fourth quarters of 2008 and the first quarter of 2009. Investment is quarterly investment as a percent of the calculated market value of capital. Growth in sales is the annual growth rate in sales. Cash flow is quarterly profits after financial income and expense minus taxes plus depreciation in percent of total assets. Cash reserves is cash and short-term assets. Credit reserves is remaining, unused credit on lines of credit. Both cash reserves and credit reserves are expressed as a percent of total assets. Used amount is the amount drawn on the lines of credit. 
Table 2. Investment before and after the financial crisis

\begin{tabular}{|c|c|c|c|c|}
\hline & Before crisis & After crisis & $\begin{array}{l}\text { t-Statistic } \\
\text { (difference) }\end{array}$ & $\begin{array}{l}\text { Change } \\
\text { between } \\
\text { periods }\end{array}$ \\
\hline \multicolumn{5}{|c|}{ Panel 1. Average investment, all firms } \\
\hline & 3.132 & 2.810 & 4.916 & $-10.3 \%$ \\
\hline \multicolumn{5}{|c|}{ Panel 2. Access to a line of credit and average investment } \\
\hline $\begin{array}{l}\text { Access to a line of } \\
\text { credit }\end{array}$ & 3.124 & 2.814 & 4.755 & $-9.9 \%$ \\
\hline No line of credit & 3.692 & 3.406 & 2.335 & $-7.8 \%$ \\
\hline \multicolumn{5}{|c|}{ Panel 3. Credit reserves and average investment } \\
\hline Low credit reserves & 3.290 & 2.864 & 3.451 & $-12.9 \%$ \\
\hline $\begin{array}{l}\text { High credit } \\
\text { reserves }\end{array}$ & 3.557 & 3.355 & 1.015 & $-5.7 \%$ \\
\hline \multicolumn{5}{|c|}{ Panel 4. Cash reserves and average investment } \\
\hline Low cash reserves & 2.827 & 2.541 & 2.818 & $-10.1 \%$ \\
\hline High cash reserves & 3.156 & 2.971 & 1.773 & $-5.9 \%$ \\
\hline
\end{tabular}

Table Notes: This table presents difference-in-means calculations of firm-level quarterly investment. Before crisis refers to the period July 1, 2007 to March 31, 2008. After crisis refers to the period July 1, 2008 to March 31, 2009. The reported means are cross-sectional averages of the sample of firms for the relevant period. Cash reserves is cash and short-term assets. Credit reserves is remaining, unused credit on the line credit. Low cash and credit reserves correspond to the first quartile. High cash and credit reserves correspond to observations above the first quartile.

Table 3. Cash reserves and investment before and after the credit crisis

\begin{tabular}{|c|c|c|c|c|}
\hline & (1) & (2) & (3) & (4) \\
\hline After & $\begin{array}{c}-0.49 * * * \\
{[0.054]}\end{array}$ & $\begin{array}{c}-0.48^{* * * * *} \\
{[0.065]}\end{array}$ & $\begin{array}{c}-0.40^{* * * * *} \\
{[0.068]}\end{array}$ & $\begin{array}{c}-0.33 * * * \\
{[0.067]}\end{array}$ \\
\hline After*Cash reserves $(\mathrm{t}-4)$ & & $\begin{array}{c}0.01 * * * \\
{[0.002]}\end{array}$ & $\begin{array}{c}0.01 * * \\
{[0.002]}\end{array}$ & $\begin{array}{c}0.00 \\
{[0.003]}\end{array}$ \\
\hline Cash reserves (t-4) & & & & $\begin{array}{c}0.01 * * * \\
{[0.005]}\end{array}$ \\
\hline Growth in sales & & & $\begin{array}{l}0.02 * * * \\
{[0.004]}\end{array}$ & $\begin{array}{c}0.02 * * * \\
{[0.004]}\end{array}$ \\
\hline Cash flow & & & $\begin{array}{c}-0.02 * * * * \\
{[0.007]}\end{array}$ & $\begin{array}{c}-0.02 * * * \\
{[0.007]}\end{array}$ \\
\hline Observations & 22,273 & 18,120 & 18,120 & 18,120 \\
\hline R-squared & 0.005 & 0.004 & 0.007 & 0.009 \\
\hline Number of firms & 5,089 & 4,222 & 4,222 & 4,222 \\
\hline
\end{tabular}

Table Notes: This table presents estimates from panel regressions explaining firm-level quarterly investment during a pre-crisis period corresponding to the last two quarters of 2007 and the first quarter of 2008 and a crisis period corresponding to the last two quarters of 2008 and the first quarter of 2009 . After is an indicator variable equal to one for observations during the crisis period. All regressions include firm fixed effects. Standard errors are heteroscedasticity-consistent and clustered at the firm-level. 
Table 4. Credit reserves and investment before and after the credit crisis

\begin{tabular}{|c|c|c|c|c|c|}
\hline & (1) & (2) & (3) & (4) & (5) \\
\hline After & $\begin{array}{c}-0.49 * * * \\
{[0.054]}\end{array}$ & $\begin{array}{c}-0.49 * * * \\
{[0.080]}\end{array}$ & $\begin{array}{c}-0.41 * * * \\
{[0.081]}\end{array}$ & $\begin{array}{c}-0.36^{* * * *} \\
{[0.082]}\end{array}$ & $\begin{array}{c}-0.31 * * * * \\
{[0.058]}\end{array}$ \\
\hline After*Credit reserves ( $\mathrm{t}-4)$ & & $\begin{array}{l}0.01^{* *} \\
{[0.007]}\end{array}$ & $\begin{array}{c}0.01 * \\
{[0.007]}\end{array}$ & $\begin{array}{c}0.01 \\
0.007]\end{array}$ & \\
\hline Credit reserves (t-4) & & & & $\begin{array}{c}0.01 \\
{[0.009]}\end{array}$ & $\begin{array}{c}0.02 * \\
{[0.009]}\end{array}$ \\
\hline Growth in sales & & & $\begin{array}{c}0.02 * * * \\
{[0.004]}\end{array}$ & $\begin{array}{c}0.02 * * * \\
{[0.004]}\end{array}$ & $\begin{array}{c}0.02 * * * * \\
{[0.004]}\end{array}$ \\
\hline Cash flow & & & $\begin{array}{c}-0.02 * * * * \\
{[0.007]}\end{array}$ & $\begin{array}{c}-0.02 * * * \\
{[0.007]}\end{array}$ & $\begin{array}{c}-0.02^{* * * *} \\
{[0.007]}\end{array}$ \\
\hline Observations & 22,273 & 18,120 & 18,120 & 18,120 & 18,120 \\
\hline R-squared & 0.005 & 0.003 & 0.007 & 0.008 & 0.007 \\
\hline Number of firms & 5,089 & 4,222 & 4,222 & 4,222 & 4,222 \\
\hline
\end{tabular}

Table Notes: This table presents estimates from panel regressions explaining firm-level quarterly investment during a pre-crisis period corresponding to the last two quarters of 2007 and the first quarter of 2008 and a crisis period corresponding to the last two quarters of 2008 and the first quarter of 2009 . After is an indicator variable equal to one for observations during the crisis period. All regressions include firm fixed effects. Standard errors are heteroscedasticity-consistent and clustered at the firm-level.

Table 5. Summary statistics of credit-constrained firms

\begin{tabular}{lll}
\hline & Credit constrained firms & Full sample \\
\hline Number of firms & 896 & 5089 \\
& & \\
Average asset size & 187.14 million $\$$ & 31.86 million $\$$ \\
Average number of employees & 159 & 45 \\
Part of group & $15 \%$ & $9 \%$ \\
\hline
\end{tabular}

Table Notes: This table reports summary statistics for the sample of firms categorized as credit-constrained observed over the pre-crisis period as well as the crisis period. 
Table 6. Investment before and after the credit crisis for credit-constrained and unconstrained firms

\begin{tabular}{|c|c|c|c|c|c|c|}
\hline & (1) & (2) & (3) & (4) & (5) & (6) \\
\hline After & $\begin{array}{c}-0.49^{* * *} * \\
{[0.054]}\end{array}$ & $\begin{array}{c}-0.46 * * * \\
{[0.055]}\end{array}$ & $\begin{array}{c}-0.36 * * * \\
{[0.059]}\end{array}$ & $\begin{array}{c}-0.37 * * * \\
{[0.060]}\end{array}$ & $\begin{array}{c}-0.27 * * * \\
{[0.061]}\end{array}$ & $\begin{array}{c}-0.30 * * * \\
{[0.061]}\end{array}$ \\
\hline After*Credit constrained ( $\mathrm{t}-4)$ & & $\begin{array}{c}-0.31 * * \\
{[0.134]}\end{array}$ & $\begin{array}{c}-0.08 \\
{[0.127]}\end{array}$ & $\begin{array}{c}-0.08 \\
{[0.127]}\end{array}$ & $\begin{array}{c}-0.07 \\
{[0.127]}\end{array}$ & $\begin{array}{c}-0.06 \\
{[0.127]}\end{array}$ \\
\hline Credit reserves $(\mathrm{t}-4)$ & & & $\begin{array}{c}0.01 * \\
{[0.009]}\end{array}$ & $\begin{array}{c}0.01 \\
{[0.009]}\end{array}$ & $\begin{array}{c}0.02 * \\
{[0.009]}\end{array}$ & $\begin{array}{c}0.02 * \\
{[0.009]}\end{array}$ \\
\hline Cash reserves (t-4) & & & & $\begin{array}{c}0.03 * * * \\
{[0.009]}\end{array}$ & $\begin{array}{c}0.03 * * * \\
{[0.009]}\end{array}$ & $\begin{array}{c}0.03 * * * \\
{[0.009]}\end{array}$ \\
\hline Growth in sales & & & & & $\begin{array}{c}0.02 * * * \\
{[0.004]}\end{array}$ & $\begin{array}{c}0.02 * * * \\
{[0.004]}\end{array}$ \\
\hline Cash flow & & & & & & $\begin{array}{c}-0.02 * * * \\
{[0.007]}\end{array}$ \\
\hline Observations & 22,273 & 22,273 & 18,120 & 18,120 & 18,120 & 18,120 \\
\hline R-squared & 0.005 & 0.005 & 0.004 & 0.006 & 0.008 & 0.010 \\
\hline Number of firms & 5,089 & 5,089 & 4,222 & 4,222 & 4,222 & 4,222 \\
\hline
\end{tabular}

Table Notes: This table presents estimates from panel regressions explaining firm-level quarterly investment during a pre-crisis period corresponding to the last two quarters of 2007 and the first quarter of 2008 and a crisis period corresponding to the last two quarters of 2008 and the first quarter of 2009. After is an indicator variable equal to one for observations during the crisis period. Credit-constrained is an indicator variable equal to one for the observations at or below the 10th percentile of credit reserves measured with a lag of four quarters. All regressions include firm fixed effects. Standard errors are heteroscedasticity-consistent and clustered at the firm-level. 
Table 7. Investment before and after the crisis with different categorizations of credit-constrained/unconstrained firms.

\begin{tabular}{|c|c|c|c|c|c|c|}
\hline & $\begin{array}{l}10 \text { per cent } \\
\text { of the firms } \\
\text { defined as } \\
\text { constrained }\end{array}$ & $\begin{array}{l}10 \text { per cent } \\
\text { of the firms } \\
\text { defined as } \\
\text { constrained }\end{array}$ & $\begin{array}{l}15 \text { per cent } \\
\text { of the firms } \\
\text { defined as } \\
\text { constrained }\end{array}$ & $\begin{array}{l}15 \text { per cent } \\
\text { of the firms } \\
\text { defined as } \\
\text { constrained }\end{array}$ & $\begin{array}{l}20 \text { per cent } \\
\text { of the firms } \\
\text { defined as } \\
\text { constrained }\end{array}$ & $\begin{array}{l}20 \text { per cent } \\
\text { of the firms } \\
\text { defined as } \\
\text { constrained }\end{array}$ \\
\hline After & $\begin{array}{c}-0.46^{* * *} * \\
{[0.055]}\end{array}$ & $\begin{array}{c}-0.30 * * * \\
{[0.061]}\end{array}$ & $\begin{array}{c}-0.47 * * * \\
{[0.057]}\end{array}$ & $\begin{array}{c}-0.32 * * * \\
{[0.062]}\end{array}$ & $\begin{array}{c}-0.47 * * * \\
{[0.057]}\end{array}$ & $\begin{array}{c}-0.32 * * * \\
{[0.063]}\end{array}$ \\
\hline After*Credit constrained (t-4) & $\begin{array}{l}-0.31 * * \\
{[0.134]}\end{array}$ & $\begin{array}{c}-0.06 \\
{[0.127]}\end{array}$ & $\begin{array}{c}-0.11 \\
{[0.114]}\end{array}$ & $\begin{array}{c}0.12 \\
{[0.117]}\end{array}$ & $\begin{array}{c}-0.09 \\
{[0.119]}\end{array}$ & $\begin{array}{c}0.08 \\
{[0.127]}\end{array}$ \\
\hline Credit reserves $(\mathrm{t}-4)$ & & $\begin{array}{c}0.02 * \\
{[0.009]}\end{array}$ & & $\begin{array}{c}0.02 * \\
{[0.009]}\end{array}$ & & $\begin{array}{c}0.02 * \\
{[0.009]}\end{array}$ \\
\hline Cash reserves (t-4) & & $\begin{array}{l}0.03 * * * \\
{[0.009]}\end{array}$ & & $\begin{array}{c}0.03 * * * \\
{[0.009]}\end{array}$ & & $\begin{array}{c}0.03 * * * \\
{[0.009]}\end{array}$ \\
\hline Growth in sales & & $\begin{array}{c}0.02 * * * \\
{[0.004]}\end{array}$ & & $\begin{array}{c}0.02 * * * \\
{[0.004]}\end{array}$ & & $\begin{array}{c}0.02 * * * \\
{[0.004]}\end{array}$ \\
\hline Cash flow & & $\begin{array}{c}-0.02 * * * \\
{[0.007]}\end{array}$ & & $\begin{array}{c}-0.02 * * * \\
{[0.007]}\end{array}$ & & $\begin{array}{c}-0.02 * * * \\
{[0.007]}\end{array}$ \\
\hline Observations & 22,273 & 18,120 & 22,273 & 18,120 & 22,273 & 18,120 \\
\hline R-squared & 0.005 & 0.010 & 0.005 & 0.010 & 0.005 & 0.010 \\
\hline Number of firms & 5,089 & 4,222 & 5,089 & 4,222 & 5,089 & 4,222 \\
\hline
\end{tabular}

Table Notes: This table presents estimates from panel regressions explaining firm-level quarterly investment during a pre-crisis period corresponding to the last two quarters of 2007 and the first quarter of 2008 and a crisis period corresponding to the last two quarters of 2008 and the first quarter of 2009. After is an indicator variable equal to one for observations during the crisis period. Credit-constrained is an indicator variable equal to one for the observations at or below the 10th, the 15th and the 20th percentile of credit reserves measured with a lag of four quarters. All regressions include firm fixed effects. Standard errors are heteroscedasticity-consistent and clustered at the firm-level. 
Table 8. Investment before and after the crisis. Constrained firms defined on the basis of both credit and cash reserves

\begin{tabular}{|c|c|c|c|c|c|}
\hline & (1) & (2) & (3) & (4) & (5) \\
\hline After & $\begin{array}{c}-0.49 * * * \\
{[0.054]}\end{array}$ & $\begin{array}{c}-0.49^{* * * *} \\
{[0.055]}\end{array}$ & $\begin{array}{c}-0.39 * * * \\
{[0.058]}\end{array}$ & $\begin{array}{c}-0.29^{* * * *} \\
{[0.060]}\end{array}$ & $\begin{array}{c}-0.32 * * * * \\
{[0.059]}\end{array}$ \\
\hline After*Constrained $(\mathrm{t}-4)$ & & $\begin{array}{c}0.00 \\
{[0.174]}\end{array}$ & $\begin{array}{c}0.14 \\
{[0.174]}\end{array}$ & $\begin{array}{c}0.15 \\
{[0.173]}\end{array}$ & $\begin{array}{c}0.17 \\
{[0.172]}\end{array}$ \\
\hline Total reserves (t-4) & & & $\begin{array}{c}0.02^{* * *} \\
{[0.006]}\end{array}$ & $\begin{array}{c}0.03^{* * * *} \\
{[0.006]}\end{array}$ & $\begin{array}{c}0.03^{* * * *} \\
{[0.006]}\end{array}$ \\
\hline Growth in sales & & & & $\begin{array}{l}0.02 * * * * \\
{[0.004]}\end{array}$ & $\begin{array}{l}0.02 * * * * \\
{[0.004]}\end{array}$ \\
\hline Cash flow & & & & & $\begin{array}{c}-0.02^{* * * *} \\
{[0.007]}\end{array}$ \\
\hline Observations & 22,273 & 22,273 & 18,120 & 18,120 & 18,120 \\
\hline R-squared & 0.005 & 0.005 & 0.005 & 0.008 & 0.009 \\
\hline Number of firms & 5,089 & 5,089 & 4,222 & 4,222 & 4,222 \\
\hline
\end{tabular}

Table Notes: This table presents estimates from panel regressions explaining firm-level quarterly investment during a pre-crisis period corresponding to the last two quarters of 2007 and the first quarter of 2008 and a crisis period corresponding to the last two quarters of 2008 and the first quarter of 2009. After is an indicator variable equal to one for observations during the crisis period. Constrained is an indicator variable equal to one for the observations at or below the 10th percentile of total reserves measured with a lag of four quarters. All regressions include firm fixed effects. Standard errors are heteroscedasticity-consistent and clustered at the firm-level. 
Figure 1. Share of firms with a line of credit

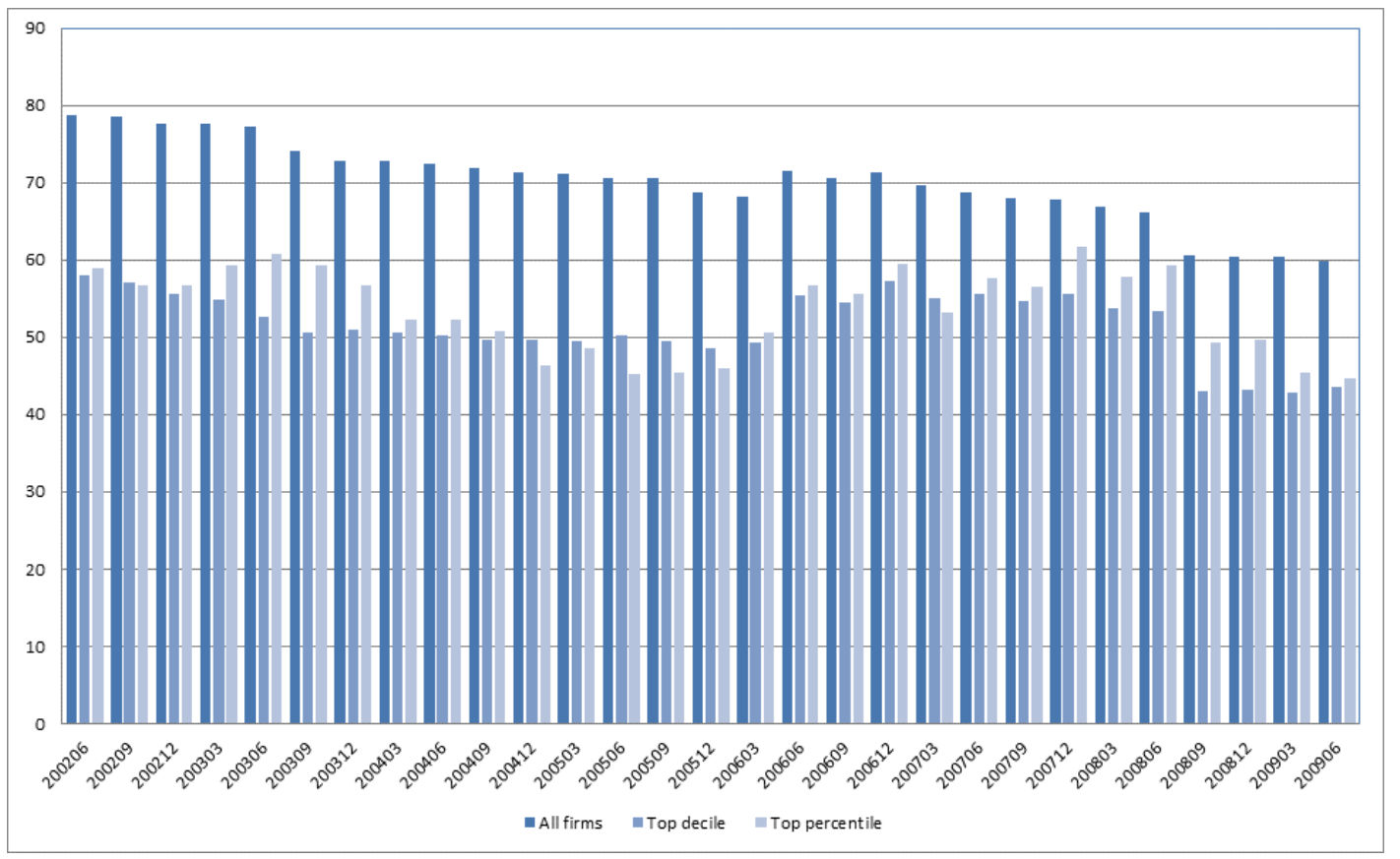

Figure Notes: The figure shows the evolution in the share of firms with a line according to the bank lending data. At each time period, it shows the percent of corporate clients, out of the total number of corporate clients of the bank, which has access to a line of credit. The top decile refers to firms which in terms of asset size are at or above the 90th percentile. The top percentile refers to firms which in terms of asset size are at or above the 99th percentile. 
Table 9. Probit estimations of the likelihood that a firm has a line of credit (marginal effects)

\begin{tabular}{|c|c|c|c|c|}
\hline & (1) & (2) & (3) & (4) \\
\hline After & $\begin{array}{c}-0.016 * * * \\
{[0.006]}\end{array}$ & $\begin{array}{c}-0.016 * * * \\
{[0.006]}\end{array}$ & $\begin{array}{c}-0.016 * * * \\
{[0.006]}\end{array}$ & $\begin{array}{c}-0.017 * * * \\
{[0.006]}\end{array}$ \\
\hline Cash flow & $\begin{array}{c}-0.388 * * * \\
{[0.053]}\end{array}$ & $\begin{array}{c}-0.383^{* * *} * \\
{[0.055]}\end{array}$ & $\begin{array}{c}-0.376^{* * *} \\
{[0.055]}\end{array}$ & $\begin{array}{c}-0.356 * * * \\
{[0.060]}\end{array}$ \\
\hline Ln (Total assets) & $\begin{array}{c}-0.046 * * * \\
{[0.004]}\end{array}$ & $\begin{array}{c}-0.046 * * * \\
{[0.004]}\end{array}$ & $\begin{array}{c}-0.052 * * * \\
{[0.004]}\end{array}$ & $\begin{array}{c}-0.061 * * * \\
{[0.005]}\end{array}$ \\
\hline Growth in sales & & $\begin{array}{c}-0.000 \\
{[0.000]}\end{array}$ & $\begin{array}{l}-0.000 \\
{[0.000]}\end{array}$ & $\begin{array}{c}0.001 * * \\
{[0.000]}\end{array}$ \\
\hline Part of group & & & $\begin{array}{c}0.074 * * * \\
{[0.019]}\end{array}$ & $\begin{array}{c}0.060 * * * \\
{[0.019]}\end{array}$ \\
\hline Cash flow volatility & & & & $\begin{array}{c}-0.140 * * * \\
{[0.025]}\end{array}$ \\
\hline Pseudo $\mathrm{R}^{2}$ & 0.03 & 0.03 & 0.04 & 0.06 \\
\hline Observations & 20,121 & 20,121 & 20,121 & 14,608 \\
\hline
\end{tabular}

Table Notes: This table reports results from probit regressions where the dependent variable takes the value 1 if the the firm has a line of credit in the current period. After is an indicator variable equal to 1 for observations during the third and fourth quarters of 2008 and the first quarter of 2009. The coefficients in each colum are estimated marginal effects of the After indicator and of firm characteristics on the probability of having a line of credit. Standard errors are clusterad at the firm level. 
Table 10. Changes in investment and changes in the probability of having a line of credit

\begin{tabular}{|c|c|c|c|c|c|c|c|c|}
\hline & $\begin{array}{l}\text { Crisis } \\
\text { period }\end{array}$ & $\begin{array}{l}\text { Crisis } \\
\text { period }\end{array}$ & $\begin{array}{c}\text { Q3 } \\
2008\end{array}$ & $\begin{array}{c}\text { Q3 } \\
2008\end{array}$ & $\begin{array}{c}\text { Q4 } \\
2008\end{array}$ & $\begin{array}{c}\text { Q4 } \\
2008\end{array}$ & $\begin{array}{c}\text { Q1 } \\
2009\end{array}$ & $\begin{array}{c}\text { Q1 } \\
2009\end{array}$ \\
\hline $\operatorname{Line}(t-1)-\operatorname{Line}(t)$ & $\begin{array}{c}-0.18 \\
{[0.239]}\end{array}$ & $\begin{array}{c}-0.24 \\
{[0.234]}\end{array}$ & $\begin{array}{c}-0.04 \\
{[0.285]}\end{array}$ & $\begin{array}{c}-0.12 \\
{[0.271]}\end{array}$ & $\begin{array}{c}-0.13 \\
{[0.380]}\end{array}$ & $\begin{array}{c}-0.23 \\
{[0.372]}\end{array}$ & $\begin{array}{c}-0.44 \\
{[0.406]}\end{array}$ & $\begin{array}{c}-0.42 \\
{[0.400]}\end{array}$ \\
\hline $\operatorname{Prob}\left[\right.$ Line $\left.=1 \mid\left(\mathrm{X}_{\mathrm{t}-1}\right)\right]-\operatorname{Prob}\left[\right.$ Line $\left.=1 \mid\left(\mathrm{X}_{\mathrm{t}}\right)\right]$ & $\begin{array}{c}2.41^{*} \\
{[1.252]}\end{array}$ & $\begin{array}{l}2.79 * * \\
{[1.324]}\end{array}$ & $\begin{array}{c}2.28 \\
{[1.807]}\end{array}$ & $\begin{array}{c}1.72 \\
{[1.895]}\end{array}$ & $\begin{array}{c}2.66^{*} \\
{[1.420]}\end{array}$ & $\begin{array}{c}2.44^{*} \\
{[1.450]}\end{array}$ & $\begin{array}{c}2.30 \\
{[1.990]}\end{array}$ & $\begin{array}{l}4.27 * \\
{[2.224]}\end{array}$ \\
\hline Cash flow & & $\begin{array}{c}0.01 * \\
{[0.004]}\end{array}$ & & $\begin{array}{c}0.01^{*} \\
{[0.005]}\end{array}$ & & $\begin{array}{l}0.01 * * * \\
{[0.005]}\end{array}$ & & $\begin{array}{c}-0.00 \\
{[0.007]}\end{array}$ \\
\hline Growth in sales & & $\begin{array}{l}0.04 * * * \\
{[0.004]}\end{array}$ & & $\begin{array}{l}0.04 * * * \\
{[0.006]}\end{array}$ & & $\begin{array}{l}0.03 * * * \\
{[0.004]}\end{array}$ & & $\begin{array}{l}0.05 * * * \\
{[0.007]}\end{array}$ \\
\hline $\begin{array}{l}\text { Observations } \\
\text { R-squared }\end{array}$ & $\begin{array}{c}11,033 \\
0.001\end{array}$ & $\begin{array}{c}11,033 \\
0.023\end{array}$ & $\begin{array}{l}3,682 \\
0.001\end{array}$ & $\begin{array}{l}3,682 \\
0.031\end{array}$ & $\begin{array}{l}3,738 \\
0.001\end{array}$ & $\begin{array}{l}3,738 \\
0.027\end{array}$ & $\begin{array}{l}3,613 \\
0.001\end{array}$ & $\begin{array}{l}3,613 \\
0.018\end{array}$ \\
\hline
\end{tabular}

Table Notes: This table presents estimates from regressions explaining firm-level quarterly investment after the onset of the crisis. Colums (1) and (2) show the results of a pooled regressions estimated over the third and fourth quarters of 2008 and the first quarter of 2009. Columns (3) and (4) are regressions over the cross-section of firms in the third quarter of 2008. Columns (5) and (6) are regressions over the cross-section of firms in the third quarter of 2008 and columns (7) and (8) show similar regressions for the first quarter of 2009. Line(t-1) is an indicator variable equal to one if the firm has a line of credit in the current quarter of the pre-crisis period. Line(t) is an indicator variable equal to one if the firm has a line of credit in the current quarter of the crisis period. Line(t- 1$)$ - Line(t) is the difference between the two indicator variables in the current quarter. Prob[Line $=1 \mid(\mathrm{X}(\mathrm{t}-1))]$ is the predicted probability of having a line of credit in the current quarter of the pre-crisis period, conditional on the value of firm-specific control variables for the current quarter. Prob[Line $=1 \mid(\mathrm{X}(\mathrm{t}))]$ is out of sample forecasts of the probability of having a line of credit in the current quarter of the crisis period. The predicted probability of having a line of credit is based on the estimated parameters for the pre-crisis period and condtioned on the firm-specific control variables for the current quarter of the crisis period. Prob $[$ Line $=1 \mid(\mathrm{X}(\mathrm{t}-1))]-\operatorname{Prob}[\operatorname{Line}=1 \mid(\mathrm{X}(\mathrm{t}))]$ is the difference between the two predictions in the current quarter. Standard errors are heteroscedasticity-consistent and clustered at the firm-level. 


\title{
Appendices
}

\section{A1. Variable definitions}

\author{
Investment $=$ Quarterly investment/Capital stock \\ Cash flow $=$ Quarterly profits after financial income and expense minus taxes plus \\ depreciation/Total assets
}

Cash flow volatility $=$ Rolling average over four years of standard deviation in cash flow

Cash reserves $=$ Cash and short term assets/Total assets

Credit reserves $=($ Total line of credit - used amount $) /$ Total assets

Growth in sales $=$ Annual growth rate in sales

Total reserves $=[($ Total line of credit - used amount $)+($ cash and short term assets $)] /$ Total

assets

\section{A2. Constructing a measure of the capital stock}

I calculate the capital stock using the perpetual inventory method with some modifications described below.

Capital is defined as the sum of machines, inventories and buildings. I calculate the depreciation rate for total capital as a weighted average of depreciation rates for machine, inventories and buildings, respectively, where I set the weights as the relative share of machine, inventories and buildings in the industry's capital.

The industry-specific depreciation rates for machines and inventories are taken from a publication by the U.S. Bureau of Economic Analysis (2003). For each Swedish industry, I use the closest possible U.S. industry-specific depreciation rate. For buildings, I use the annual depreciation rate of 0.0314 for all sectors, which is taken from the same publication. The corresponding quarterly depreciation rates are presented in table A1 below.

The nominal price of capital is calculated from gross fixed capital formation in current and fixed prices, respectively (from national accounts data available on the web page of Statistics Sweden).

According to the perpetual inventory method the replacement cost of capital is calculated as

$$
K_{i, t}=\left(1-\delta_{i, t}\right) K_{i, t-1} \frac{p_{t}^{k}}{p_{t-1}^{k}}+I_{i, t}
$$

where $K_{i, t}$ is the nominal capital stock of firm $i$ at the end of period $t, \delta_{i, t}$ is the depreciation rate, $p_{t}^{k}$ is the price of capital and $I_{i, t}$ is the nominal investment during period $t$. The recursive formula requires an initial value for capital which is commonly set equal to the initial book value of capital $\left(K_{i, 0}^{b}\right)$. However, it turns out that for the sample of firms I study, using the book value of capital as $K_{i, 0}$ gives an average ratio $I / K$ with a downward trend (see figure A1). An interpretation is that the initial book values of capital are too low on average.

To adjust for this, and to get a stationary $I / K$ series, I calculate the replacement cost of capital in two steps. In the first step, I calculate the replacement cost of capital according to (4) where I use book values to approximate $K_{i, 0}$. In the second step, I use a new estimate $K_{i, 0}$ by calculating an industry-weighted average ratio of $K_{i, T} / K_{i, T}^{b}$ and multiplying $K_{i, 0}^{b}$ with this ratio. With this new initial value, I calculate a new estimate of the replacement cost of capital according to (4).

In principle, one can iterate along these lines until convergence is achieved in the sense that $K_{i, T}$ is robust to additional iterations. It can be shown that, under the condition that $K_{i, 0}^{b} / K_{i, T}^{b}<1$, the value of $K_{i, T}$ will converge. 
However, this conditions holds for only approximately half of the firms in my sample. Therefore, I iterate only once. Still, I get an average ratio $I / K$ where there is no longer a declining trend. The result is show in figure A1.

Table A1. Industry-specific depreciation rates for machines and inventories

\begin{tabular}{ll} 
Industry & Machines and inventories \\
\hline Agriculture & 0.1179 \\
Manufacturing & 0.1225 \\
Construction & 0.1550 \\
Retail & 0.1650 \\
Hotel, restaurant & 0.1500 \\
Transport & 0.1725 \\
Real estate & 0.1473 \\
Consulting & 0.3119 \\
Residual category & 0.1473
\end{tabular}

Source: Fixed Assets and Consumer Durable Goods in the United States, 1925-97, U.S. Department of Commerce, September 2003.

Figure A1. Average investment ratio with replacement cost of capital measured according to two variants of the perpetual inventory method

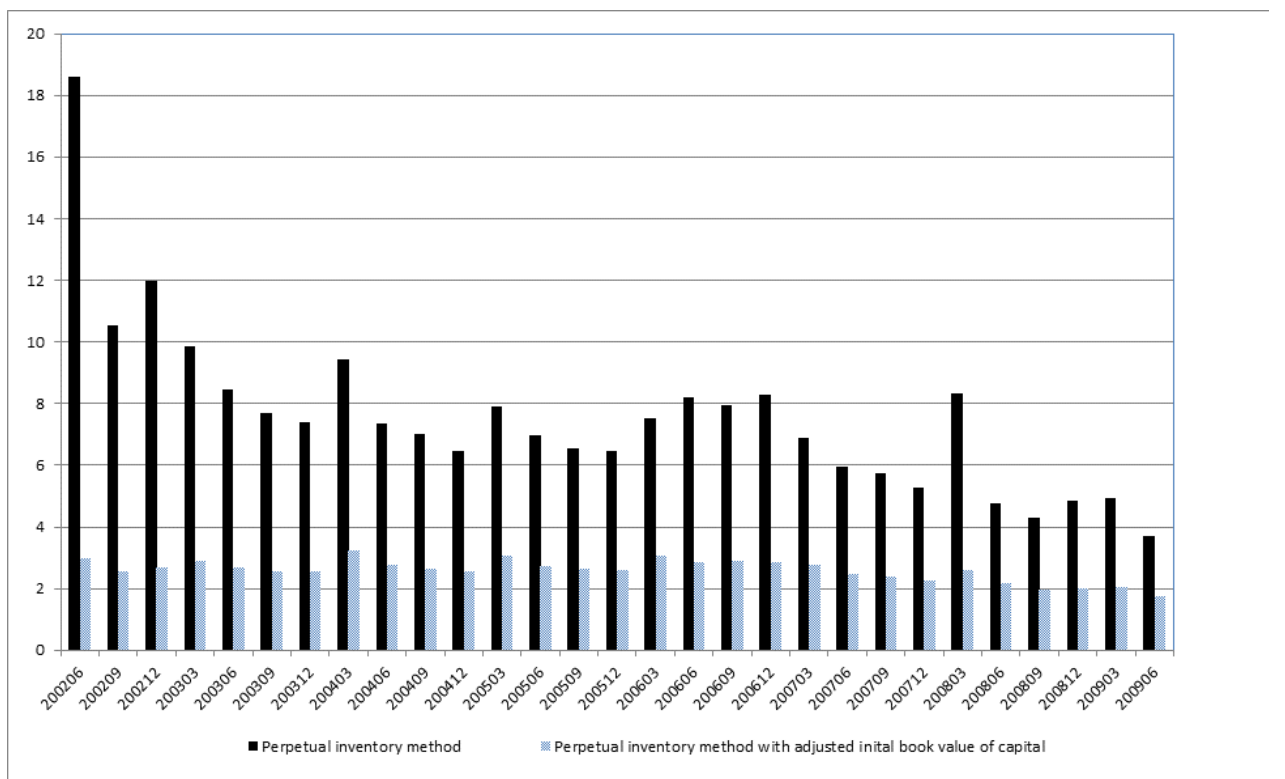

Figure Notes: The figure shows estimates of the average ratio of investment to capital of the cross-section of firms in each period. Dark bars show the replacement cost of capital calculated with the perpetual inventory method. Light bars show an adjusted version of the perpetual inventory method explained above. 


\section{A3. Panel regressions over subsamples of firms with different fiscal year periods}

Table A2. Investment before and after the crisis for different subsamples of firms

\begin{tabular}{|c|c|c|c|c|c|c|c|c|}
\hline & $\begin{array}{c}\text { Full } \\
\text { sample }\end{array}$ & $\begin{array}{c}\text { Full } \\
\text { sample }\end{array}$ & $\begin{array}{l}\text { Closing } \\
\text { time of } \\
\text { financial } \\
\text { statements } \\
\text { in April or } \\
\text { June }\end{array}$ & $\begin{array}{l}\text { Closing } \\
\text { time of } \\
\text { financial } \\
\text { statements } \\
\text { in April or } \\
\text { June }\end{array}$ & $\begin{array}{l}\text { Closing } \\
\text { time of } \\
\text { financial } \\
\text { statements } \\
\text { in June }\end{array}$ & $\begin{array}{l}\text { Closing } \\
\text { time of } \\
\text { financial } \\
\text { statements } \\
\text { in June }\end{array}$ & $\begin{array}{l}\text { Closing } \\
\text { time of } \\
\text { financial } \\
\text { statements } \\
\text { in } \\
\text { December }\end{array}$ & $\begin{array}{l}\text { Closing } \\
\text { time of } \\
\text { financial } \\
\text { statements } \\
\text { in } \\
\text { December }\end{array}$ \\
\hline After & $\begin{array}{c}-0.49 * * * \\
{[0.080]}\end{array}$ & $\begin{array}{c}-0.36 * * * \\
{[0.082]}\end{array}$ & $\begin{array}{c}-0.29 * \\
{[0.156]}\end{array}$ & $\begin{array}{c}-0.30 * \\
{[0.175]}\end{array}$ & $\begin{array}{c}-0.07 \\
{[0.253]}\end{array}$ & $\begin{array}{c}-0.20 \\
{[0.261]}\end{array}$ & $\begin{array}{c}-0.61 * * * \\
{[0.109]}\end{array}$ & $\begin{array}{c}-0.42 * * * \\
{[0.106]}\end{array}$ \\
\hline After*Credit reserves $(\mathrm{t}-4)$ & $\begin{array}{c}0.01 * * \\
{[0.007]}\end{array}$ & $\begin{array}{c}0.01 \\
{[0.007]}\end{array}$ & $\begin{array}{c}0.01 \\
{[0.011]}\end{array}$ & $\begin{array}{c}0.01 \\
{[0.013]}\end{array}$ & $\begin{array}{c}0.01 \\
{[0.019]}\end{array}$ & $\begin{array}{c}0.01 \\
{[0.022]}\end{array}$ & $\begin{array}{c}0.02 * \\
{[0.009]}\end{array}$ & $\begin{array}{c}0.01 \\
{[0.009]}\end{array}$ \\
\hline Credit reserves $(\mathrm{t}-4)$ & & $\begin{array}{c}0.01 \\
{[0.009]}\end{array}$ & & $\begin{array}{c}-0.01 \\
{[0.016]}\end{array}$ & & $\begin{array}{c}-0.01 \\
{[0.019]}\end{array}$ & & $\begin{array}{c}0.02^{*} \\
{[0.013]}\end{array}$ \\
\hline Growth in sales & & $\begin{array}{c}0.02 * * * \\
{[0.004]}\end{array}$ & & $\begin{array}{c}0.01 \\
{[0.009]}\end{array}$ & & $\begin{array}{c}0.00 \\
{[0.016]}\end{array}$ & & $\begin{array}{c}0.03 * * * \\
{[0.006]}\end{array}$ \\
\hline Cash flow & & $\begin{array}{c}-0.02 * * * \\
{[0.007]}\end{array}$ & & $\begin{array}{c}-0.01 \\
{[0.014]}\end{array}$ & & $\begin{array}{c}-0.04 \\
{[0.024]}\end{array}$ & & $\begin{array}{c}-0.03 * * * \\
{[0.009]}\end{array}$ \\
\hline Observations & 18,120 & 18,120 & 4,864 & 4,864 & 2,060 & 2,060 & 10,405 & 10,405 \\
\hline $\mathrm{R}$-squared & 0.003 & 0.008 & 0.001 & 0.002 & 0.000 & 0.003 & 0.006 & 0.014 \\
\hline Number of firms & 4,222 & 4,222 & 1,124 & 1,124 & 481 & 481 & 2,454 & 2,454 \\
\hline
\end{tabular}

Table Notes: This table presents estimates from panel regressions explaining firm-level quarterly investment during a pre-crisis period corresponding to the last two quarters of 2007 and the first quarter of 2008 and a crisis period corresponding to the last two quarters of 2008 and the first quarter of 2009. After is an indicator variable equal to one for observations during the financial crisis. The third and the fourth columns only include firms with financial statements with closing dates on April 30 or June 30. The fourth and the fifth colums only include firms with financial statements with closing date on June 30. The last two colums to the right only include firms with financial statements with closing dates on December 31. All regressions include firm fixed effects. Standard errors are heteroscedasticity-consistent and clustered at the firm-level. 


\section{Earlier Working Papers:}

For a complete list of Working Papers published by Sveriges Riksbank, see www.riksbank.se/en/Research/

Estimation of an Adaptive Stock Market Model with Heterogeneous Agents

2005:177

by Henrik Amilon

Some Further Evidence on Interest-Rate Smoothing: The Role of Measurement Errors in the Output Gap

by Mikael Apel and Per Jansson

Bayesian Estimation of an Open Economy DSGE Model with Incomplete Pass-Through

by Malin Adolfson, Stefan Laséen, Jesper Lindé and Mattias Villani

Are Constant Interest Rate Forecasts Modest Interventions? Evidence from an Estimated Open Economy

DSGE Model of the Euro Area

by Malin Adolfson, Stefan Laséen, Jesper Lindé and Mattias Villani

Inference in Vector Autoregressive Models with an Informative Prior on the Steady State by Mattias Villani

Bank Mergers, Competition and Liquidity

by Elena Carletti, Philipp Hartmann and Giancarlo Spagnolo

Testing Near-Rationality using Detailed Survey Data

$2005: 180$

by Michael F. Bryan and Stefan Palmqvist

Exploring Interactions between Real Activity and the Financial Stance

by Tor Jacobson, Jesper Lindé and Kasper Roszbach

Two-Sided Network Effects, Bank Interchange Fees, and the Allocation of Fixed Costs

by Mats $A$. Bergman

Trade Deficits in the Baltic States: How Long Will the Party Last?

by Rudolfs Bems and Kristian Jönsson

Real Exchange Rate and Consumption Fluctuations follwing Trade Liberalization

by Kristian Jönsson

Modern Forecasting Models in Action: Improving Macroeconomic Analyses at Central Banks

by Malin Adolfson, Michael K. Andersson, Jesper Lindé, Mattias Villani and Anders Vredin

Bayesian Inference of General Linear Restrictions on the Cointegration Space

2005:182

by Mattias Villani

Forecasting Performance of an Open Economy Dynamic Stochastic General Equilibrium Model

by Malin Adolfson, Stefan Laséen, Jesper Lindé and Mattias Villani

Forecast Combination and Model Averaging using Predictive Measures

by Jana Eklund and Sune Karlsson

Swedish Intervention and the Krona Float, 1993-2002

2005:183

by Owen F. Humpage and Javiera Ragnartz

A Simultaneous Model of the Swedish Krona, the US Dollar and the Euro

2005:184

by Hans Lindblad and Peter Sellin

Testing Theories of Job Creation: Does Supply Create Its Own Demand?

by Mikael Carlsson, Stefan Eriksson and Nils Gottfries

Down or Out: Assessing The Welfare Costs of Household Investment Mistakes

2005:185

by Laurent E. Calvet, John Y. Campbell and Paolo Sodini

Efficient Bayesian Inference for Multiple Change-Point and Mixture Innovation Models

by Paolo Giordani and Robert Kohn

Derivation and Estimation of a New Keynesian Phillips Curve in a Small Open Economy

by Karolina Holmberg

Technology Shocks and the Labour-Input Response: Evidence from Firm-Level Data

2005:187

by Mikael Carlsson and Jon Smedsaas

Monetary Policy and Staggered Wage Bargaining when Prices are Sticky

by Mikael Carlsson and Andreas Westermark

2005:188

The Swedish External Position and the Krona

2005:189

$2005: 190$

2005:191

by Philip R. Lane 
Evaluating Microfoundations for Aggregate Price Rigidities: Evidence from Matched Firm-Level Data on

Monetary Policy Trade-Offs in an Estimated Open-Economy DSGE Model

by Malin Adolfson, Stefan Laséen, Jesper Lindé and Lars E. O. Svensson

Flexible Modeling of Conditional Distributions Using Smooth Mixtures of Asymmetric

Student T Densities

by Feng Li, Mattias Villani and Robert Kohn

Forecasting Macroeconomic Time Series with Locally Adaptive Signal Extraction

Risk Premiums and Macroeconomic Dynamics in a Heterogeneous Agent Model

by Ferre De Graeve, Maarten Dossche, Marina Emiris, Henri Sneessens and Raf Wouters

Picking the Brains of MPC Members

by Mikael Apel, Carl Andreas Claussen and Petra Lennartsdotter

Involuntary Unemployment and the Business Cycle

by Lawrence J. Christiano, Mathias Trabandt and Karl Walentin

Housing collateral and the monetary transmission mechanism

by Karl Walentin and Peter Sellin

The Discursive Dilemma in Monetary Policy

by Carl Andreas Claussen and Øistein Røisland

Monetary Regime Change and Business Cycles

by Luca Sala, Ulf Söderström and Antonella Trigari

Density-Conditional Forecasts in Dynamic Multivariate Models by Michael K. Andersson, Stefan Palmqvist and Daniel F. Waggoner

Anticipated Alternative Policy-Rate Paths in Policy Simulations

The Effects of Endogenuos Firm Exit on Business Cycle Dynamics and Optimal Fiscal Policy 
Sveriges Riksbank

Visiting address: Brunkebergs torg 11

Mail address: se-103 37 Stockholm

Website: www.riksbank.se

SVERIGES Telephone: +46 878700 00, Fax: +46 8210531

RIKSBANK E-mail: registratorn@riksbank.se 